\title{
The Andes climate and weather
}

\author{
R. D. Garreaud \\ Department of Geophysics, Universidad de Chile, Santiago, Chile
}

Received: 2 July 2009 - Revised: 6 August 2009 - Accepted: 9 August 2009 - Published: 13 October 2009

\begin{abstract}
This paper documents the main features of the weather, climate and climate variability over Andes cordillera in South America on the basis of instrumental observations. We first provide a basic physical understanding of the mean annual cycle of the atmospheric circulation and precipitation and over the Andes and adjacent lowlands. In particular, the diversity of precipitation, temperature and wind patterns is interpreted in terms of the long meridional extent of the Andes and the disruption of the large-scale circulation by this formidable topographic barrier. We also document the impact of the El Niño Southern Oscillation phenomenon on the temperature and precipitation regimes along the Andes.
\end{abstract}

\section{Introduction}

The Andes are the most important mountain range in the Southern Hemisphere (Fig. 1), running continuously near the west coast of South America from Colombia $\left(\sim 10^{\circ} \mathrm{N}\right)$ to the southern tip of the continent $\left(\sim 53^{\circ} \mathrm{S}\right)$. Mean maximum (peak) heights of the Andes are in excess of $4000 \mathrm{~m}$ a.s.l. along their tropical and subtropical portions. South of $35^{\circ} \mathrm{S}$ the mean height decreases to about 1500 m a.s.l., but many peaks reach above $3000 \mathrm{~m}$ a.s.l. In contrast with their altitude, the Andes are a relatively narrow range with a typical width of less than $200 \mathrm{~km}$, except at subtropical latitudes where they split into two mountain ranges and contain the South American Altiplano, an elongated, high level (4000 m a.s.l.) plateau, second only to the Tibetan Plateau in surface and altitude.

Consistent with their impressive length, continuity and height, the Andes significantly disrupt the atmospheric cir-

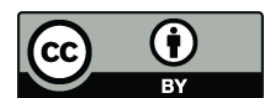

Correspondence to: R. D. Garreaud (rgarreau@dgf.uchile.cl) culation resulting in a variety of mesoscale (horizontal scales ranging from a few to several hundred $\mathrm{Km}$ ) and synoptic scale $(>1000 \mathrm{Km})$ phenomena, as well as sharply contrasting climate conditions along the eastern and western slopes and adjacent lowlands. Between $5^{\circ} \mathrm{S}-30^{\circ} \mathrm{S}$ (tropical and subtropical latitudes), relatively cold and arid conditions prevail along the Pacific coast extending well into the Andes western slopes, while warm, moist and rainy conditions prevail over the eastern slopes. This gradient reverses south of $35^{\circ} \mathrm{S}$, with temperate rainy forests along southern Chile and precipitation maxima over the western slope of the Andes, while semiarid conditions are present immediately to the east leading to the temperate steppes of the Argentina's Patagonia. Furthermore, the El Niño-Southern Oscillation (ENSO) and other planetary scale phenomena impact the Andean climate differently along its length. In this contribution, we review the climatological features of the Andes at tropical, subtropical and extratropical latitudes, and document some of the weather patterns that characterize this mountain range. We also present a physically based picture of the ENSO impacts on precipitation and temperature along the Andes.

In the context of this review, it is worth noting that the Andes meteorology and climate have been studied less than other major mountain ranges in the world. For instance, one can search the American Meteorological Society (AMS) database (available on-line at www.ametsoc.org) that publishes some of the world's leading atmospheric science journals (e.g., Journal of Climate and Monthly Weather Review) and find 122 articles with the words Andes or Andean in their title/abstract in the last 40 years. A similar search with the words Rockies or Tibet results in 357 and 211 articles, respectively. About a third of the papers are devoted to the effect of the Andes on weather systems, mainly in subtropical latitudes. Another third of the papers is devoted to the effect of the Andes on continental- to planetary-scale circulation, both in the form of dry dynamics (e.g., planetary waves) and also moist dynamics (e.g., indirect effects of precipitation).

Published by Copernicus Publications on behalf of the European Geosciences Union. 


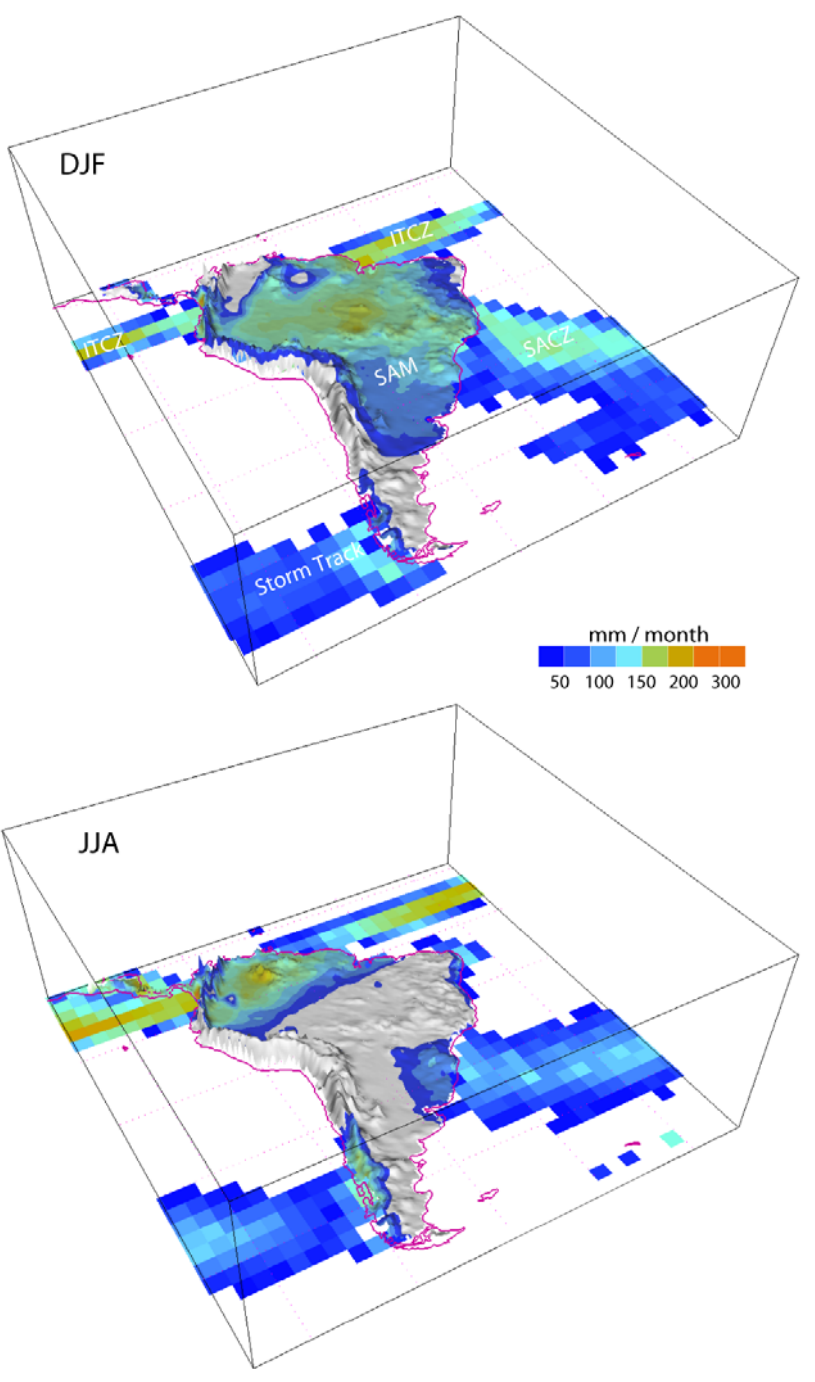

Fig. 1. Climatological (long-term mean) precipitation over South America displayed over terrain elevation for austral summer (December-January-February, top) and winter (June-July-August, bottom). The continental precipitation was obtained from the University of Delaware database on a $0.5^{\circ} \times 0.5^{\circ}$ lat-lon grid that was constructed from interpolating surface stations (Legates and Willmont, 1999). The precipitation over ocean was obtained from the CMAP dataset on a $2.5^{\circ} \times 2.5^{\circ}$ lat-lon grid that was constructed from merging satellite data and surface observations (Adler et al., 2003).

A small fraction of the papers is devoted to local-scale effects (e.g., down slope windstorms), deep convection over the mountains and meteorology of the austral Andes. This is perhaps due to a lack of in-situ observations with sufficient density and temporal resolution to resolve these mesoscale phenomena.

\section{Large-scale circulation}

Because the Andes extend from north of the equator to $53^{\circ} \mathrm{S}$, they are sensitive the tropical and extratropical upper-level large-scale circulation, characterized by moderate easterly wind at low latitudes $\left( \pm 15^{\circ}\right.$ of latitude) and westerly winds at subtropical/extratropical latitudes. This structure is shown in Fig. 2 by a pressure-longitude cross section of the seasonal mean zonal wind. During austral summer (DJF) light easterly flow extends down to $21^{\circ} \mathrm{S}$. An important factor in the southward extent of the easterlies is the establishment of the upper level Bolivian High (BH, centred at $17^{\circ} \mathrm{S} / 70^{\circ} \mathrm{W}$ ). The $\mathrm{BH}$ is a distinctive feature of the summertime circulation over South America which is induced by the deep convection over Amazon basin (e.g., Lenters and Cook, 1997). Further, during summer months the subtropical westerly jet weakens and reaches its southernmost position. In contrast, during austral winter (JJA) the easterly winds are restricted to the north of $10^{\circ} \mathrm{S}$ and the subtropical westerly jet becomes stronger with its core at $30^{\circ} \mathrm{S}$.

Low-level flow (below $\sim 1.5 \mathrm{~km}$ ) near the Andes, schematized in Fig. 3, is more complex than its upper-level counterpart. The low level flow is of particular importance because it transports most of the water vapour thus controlling the precipitation field as described in Sect. 3. The cordillera intercepts the equatorial belt of low pressure, the subtropical area of high pressure and the extratropical westerlies. Warming over the interior of the continent produces an area of relative low pressure over central South America that prevails year round (Seluchi et al., 2003), interrupting the subtropical belt of high pressure and thus forming surface anticyclones over the subtropical South Pacific and South Atlantic. As a result, the prevailing low-level winds between $\sim 35^{\circ} \mathrm{S}$ and $10^{\circ} \mathrm{S}$ blow from the south along the Pacific coast (west of the Andes) and from the north along the eastern slopes. This reversed meridional flow at each side of the subtropical Andes is shown in Fig. 4 by a longitud-pressure cross section of the meridonal component of the wind. This figure also reveals a northerly jet (i.e., a maximum in wind speed) immediately to the west of the Andes between 2000 and $5000 \mathrm{~m}$ a.s.1. that results from the mechanical blocking of the Andes upon the prevailing westerly wind in the middle troposphere (e.g., Rutllant and Garreaud, 2004; Kalthoff et al., 2002). South of $35^{\circ} \mathrm{S}$, the surface pressure decreases poleward and lowlevel westerly flow prevails year round, with a broad maximum between $45-55^{\circ} \mathrm{S}$. The westerly flow and the midlatitude waves embedded in it are able to cross the extratropical Andes cordillera, although they are strongly modified during their passage (Sect. 5).

\section{The mean precipitation field}

Broadly speaking, the tropical Andes receive precipitation from deep convective storms that develop over the mountain 

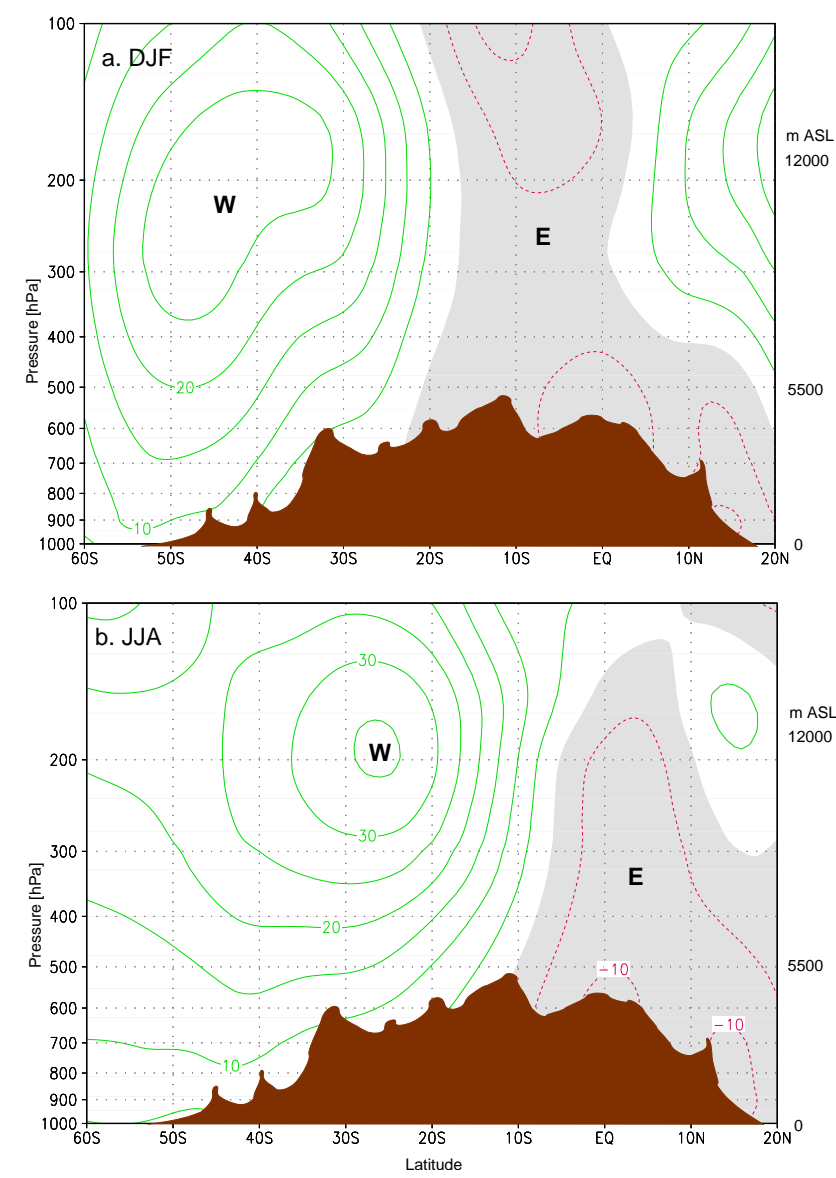

Fig. 2. Pressure-latitude cross section of the long-term mean zonal wind averaged between $80-60^{\circ} \mathrm{W}$, for austral summer (DJF, top) and winter (JJA, bottom). Positive contour interval is $10 \mathrm{~m} / \mathrm{s}$ (solid green lines). Negative contour interval is $5 \mathrm{~m} / \mathrm{s}$ (red dashed lines). Areas with easterly flow are shown in grey. Brown area indicates mean Andes height. Data source: NCEP-NCAR reanalysis (Kalnay et al., 1996).

range while south of about $25^{\circ} \mathrm{S}$ the precipitation is more stable, produced by the passage of extratropical frontal systems and cutoff lows (Fig. 1). In the free troposphere the $0{ }^{\circ} \mathrm{C}$ isotherm slopes from about $4000 \mathrm{~m}$ a.s.l. at tropical/subtropical latitudes down to about $500 \mathrm{~m}$ over the southern tip of the continent. Consistently, snow only falls over the highest Andean peaks from Colombia to northern Chile, but becomes more prevalent in the slopes of the subtropical and southern Andes, especially during cold winter storms.

The eastern and western slopes of the equatorial Andes (Ecuador and Colombia) experience rainfall fed by moist air coming from both the Amazon basin and the Gulf of Panama (e.g., Bendix et al., 2005). Precipitation over the eastern slope of the Andes is, however, extremely high because the mid-level easterly flow (trade winds) blowing from the Amazon basin transport huge quantities of water vapour (Emck, 2007). In situ observations in this region suggest

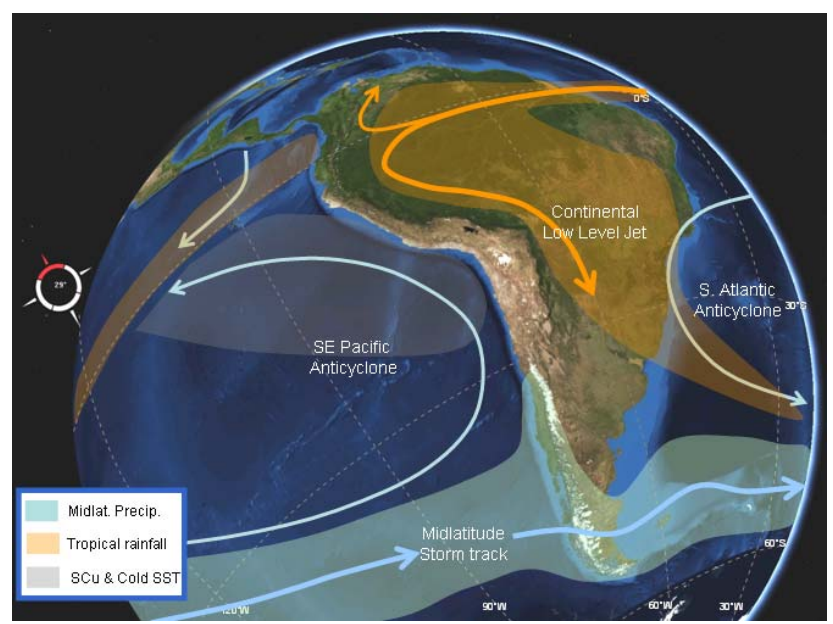

Fig. 3. Schematics of the low-level atmospheric flow (roughly from surface to about $1.5 \mathrm{~km}$ a.s.l.) around the Andes cordillera. Also shown major climate features of South America.

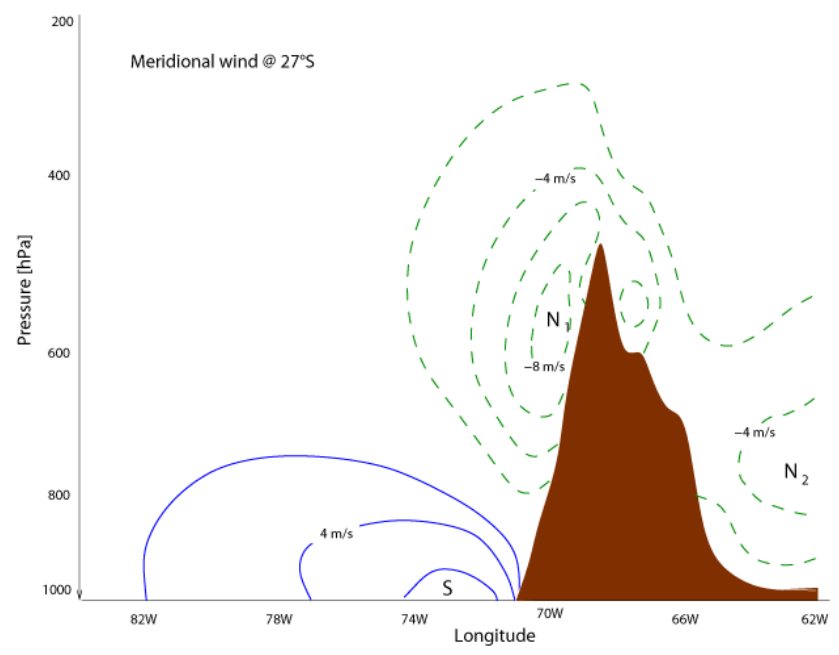

Fig. 4. Pressure-longitude cross section of the meridonal wind at $27^{\circ} \mathrm{S}$ during austral spring (SON). Contour interval is $2 \mathrm{~m} / \mathrm{s}$, the zero line is omitted and negative values in dashed lines. The brown area represents the Andes profile at this latitude. To the west of the Andes there is a southerly low-level jet (signalled by an S) just off the coast and a northerly jet (signalled by N1) close to the Andean slope. To the east of the Andes there is evidence of the northerly low-level jet (signalled by N2). Data source: PRECIS simulation of the present day climate.

an increase of precipitation with altitude to a maximum of $\sim 6000 \mathrm{~mm} /$ year at the top of the Ecuadorian Andes. This large precipitation is due to enhanced orographic rainfall and the permanent drizzle from orographic clouds (Emck, 2007). The presence of the Cauca and Magdalena valleys along the Colombian Andes also causes a very complex distribution of rainfall with alternating bands of humid and hyper-humid conditions (Lopez and Howell, 1967; Poveda et al., 2005). North of $2^{\circ} \mathrm{S}$, the Andes also experience two rainy seasons, 
around late fall and spring, in connection with the meridional displacement of the Intertropical Convergence Zone (ITCZ) over the eastern Pacific. The semi-annual cycle of rainfall rapidly fades as one moves south; over the Andes of Ecuador and northern Peru the precipitation is more concentrated during the austral fall when the ITCZ reaches its southernmost position (off the coast, the ITCZ hardly moves to the south of the equator because the cold waters over the SE Pacific inhibit the development of deep convection; e.g., Mitchell and Wallace, 1995).

The gentle descent of air (subsidence) that maintains the subtropical anticyclone over the SE Pacific is the primary cause of the arid, stable conditions along northern Chile and southern Peru coast that extend inland over the western slope of the Andes (Hartley and Houston, 2003). The southerly wind at the sea surface promotes upwelling of cold waters along the coast, which forces enhanced subsidence in order to maintain thermal balance and, hence, further drying within this region. The subsidence also maintains an inversion layer at about $1000 \mathrm{~m}$ a.s.l. that, in conjunction with the sharp coastal topography, prevents the inland penetration of the moist air in contact with the ocean (Rutllant et al., 2003).

To the east of the subtropical Andes, the continental low over the Chaco region $\left(\sim 22^{\circ} \mathrm{S}\right.$; Seluchi et al., 2003) drives northerly flow that usually features a low-level jet (LLJ) structure with its core at about $1 \mathrm{~km}$ a.g.l. and about $200 \mathrm{~km}$ east of the Andean foothills (Saulo et al., 2000; Marengo et al., 2004; see also Fig. 4). The northerly LLJ transports vast amounts of water vapour from the Amazon basin into the subtropical plains of the continent feeding the convective storms that develop during summertime in southern Brazil, Bolivia and northern Argentina, in what is now referred to as the South American Monsoon (Chou and Lau, 1998; Vera et al., 2006).

The east-west precipitation contrast is maximum between $18-23^{\circ} \mathrm{S}$ with the Atacama Desert on one side of the Andes and the Chaco wetlands on the other. Many authors have attributed the dryness of the Atacama to the rain-shadow effect of the Andes that supposedly blocks the moisture from the interior of the continent (e.g., Huston and Hartley, 2003). Nevertheless, modelling studies in which the Andes height is reduced don't result in more humid conditions over Atacama. The coastal desert remains under strong subsidence and receiving cool, dry air from the Pacific (Lenters and Cook, 1995; Sepulchre et al., 2008; Ehlers and Poulsen, 2009; Garreaud et al., 2009). This finding is of particular relevance for the paleo-climate and geological community working on the relationship between Andean uplift and the onset of hyper arid conditions over the Atacama during the Miocene (e.g., Garreaud et al., 2009). Lowering the Andes, however, does weaken the South American Monsoon and increases precipitation over northern Amazonia, emphasizing the key role of the Andes in shaping the rainfall distribution over the interior of the continent (Lenters and Cook, 1995), especially during austral summer.
In between the coastal desert and the humid lowlands of Bolivia and Brazil, the South American Altiplano exhibits its own climate conditions. In addition to the low temperatures, low air density and high radiative input by virtue of its altitude (e.g., Aceituno, 1993), the Altiplano remains extremely dry during most of the year with the exception of the austral summer (November to March) when intense convective storms bring significant precipitation to the plateau. The crucial ingredients of this seasonal rainfall are the destabilization of the local troposphere by the intense surface heating and the establishment of upper-level easterly winds that favour the transport of moist air from the interior of the continent (Garreaud et al., 2003; Vuille et al., 2003; Falvey and Garreaud, 2006). The mid-tropospheric westerly flow during the rest of the year is just too dry to sustain any convective activity. There is also substantial sub-monthly rainfall variability during summer; rainy days tend to cluster in episodes lasting about a week when the Bolivian High is more intense and displaced southward (Garreaud, 1999), separated by dry spells of similar duration. Summer precipitation over the Altiplano also exhibits a considerable meridional gradient, with much more humid conditions in its northern half than its southern half, as evident from the contrasting conditions around Lake Titicaca and Uyuni dry lake, respectively.

South of $35^{\circ} \mathrm{S}$, the area of low precipitation shifts to the east of the Andes, thus creating the dry diagonal of the continent. At midlatitudes, the west coast of the continent (southern Chile) receives abundant precipitation associated with the passage of frontal systems moving eastward from the $\mathrm{Pa}-$ cific. The latitudinal band of maximum precipitation coincides with the intersection of the coastline and the storm track: $45-55^{\circ} \mathrm{S}$ in summer and $35-45^{\circ} \mathrm{S}$ in winter. Precipitation tends to increase inland, as the moist air is forced to ascend over the western slope of the Andes, up to a maximum just upstream (i.e., westward) of the Andean ridge. This orographic enhancement of precipitation produces annual totals as high as $6000 \mathrm{~mm}$ at $45^{\circ} \mathrm{S}$, supporting the temperate rain forest, major rivers, glaciers and ice fields that characterize the Chilean Patagonia. Little moisture is left in the air masses after they cross the southern Andes toward Argentina (Smith and Evans, 2007) and the annual mean precipitation decreases to less than $100 \mathrm{~mm}$ within $100 \mathrm{~km}$ east of the Andean ridge. Downslope winds further contribute to the drying of the Argentina's Patagonia, characterized by a cold, windy steppe.

\section{Interannual variability and ENSO impacts}

The El Niño - Southern Oscillation (ENSO) is a coupled ocean-atmosphere phenomenon characterized by irregular fluctuations (2-7 year periodicity) between warm (El Niño) and cold (La Niña) conditions over the equatorial Pacific, along with other climate anomalies worldwide (e.g., Diaz and Markgraf, 1992). Alternating El Niño and La Niña 

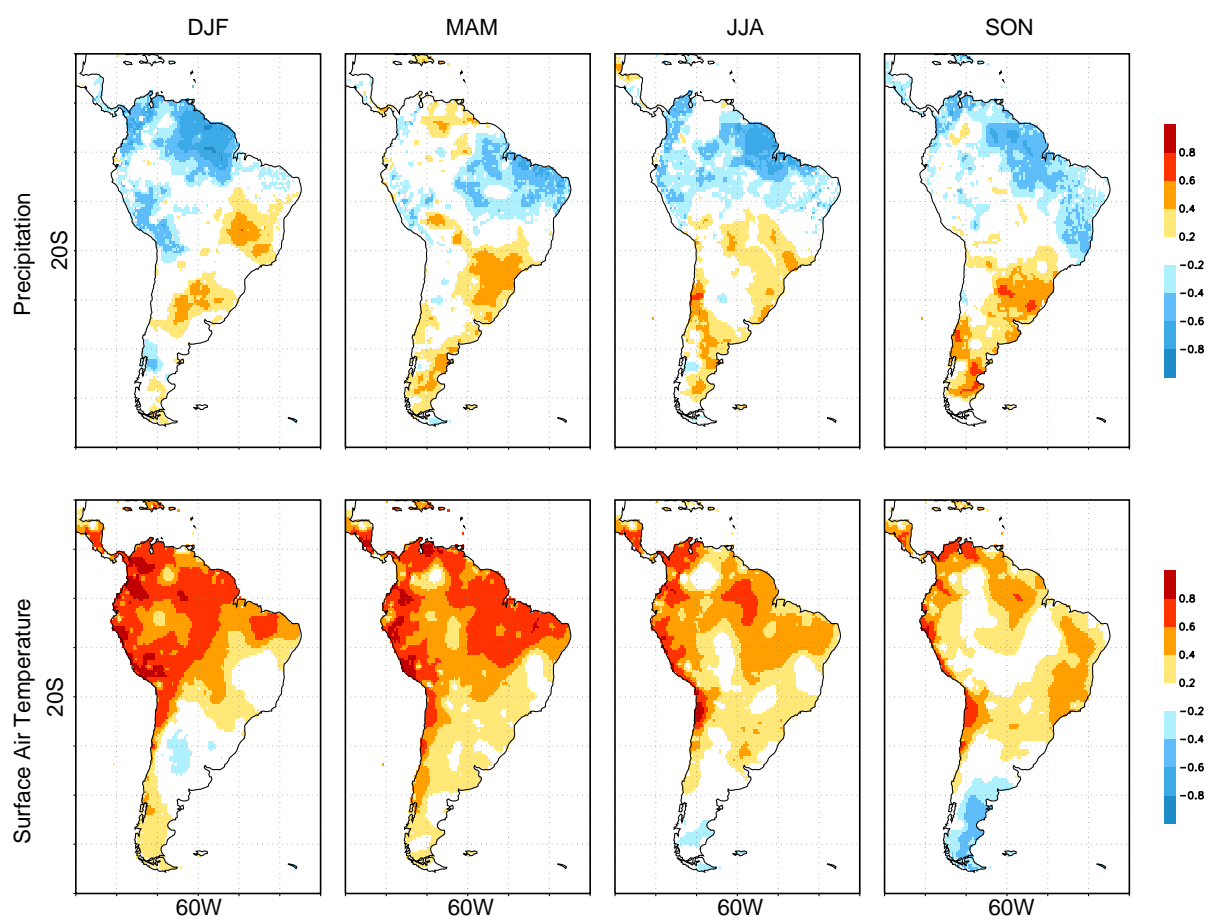

Fig. 5. Seasonal correlation map between the Multivariate ENSO Index (MEI, Wolter and Timlin, 1998) and precipitation (upper row) and surface air temperature (lower row). Gridded fields from University of Delaware (1950-1999). Only correlations in excess of \pm 0.2 are shown (roughly the threshold of the $95 \%$ significance level).

events are the major source of interannual variability over much of South America and, not surprisingly, ENSO-related variability has received considerable attention (see a review in Garreaud et al., 2008). The overall pattern is that El Niño episodes are associated with (a) below average rainfall over tropical South America, (b) above average precipitation over subtropical South America, and (c) warmer than normal air temperature at tropical and subtropical latitudes (Fig. 5). Generally opposite conditions prevail during La Niña episodes.

The precipitation decrease over northern South America during El Niño years has been attributed to a relaxed landsea thermal contrast and enhanced subsidence forced by deep convection over the eastern Pacific ITCZ (Poveda et al., 2001). The precipitation signal is integrated by the Cauca and Magdalena rivers in the Colombian Andes, with a clear tendency to above (below) normal stream flow during La Niña (El Niño) years (Aceituno and Garreaud, 1995). The equatorial Andes also experience below normal precipitation during El Niño episodes (Vuille et al., 2000; Francou et al., 2004) due to anomalous Hadley cell subduing convection over the high terrain. The Andean signal is in sharp contrast with the conditions just a few hundreds kilometres to the west (sometimes extending to the Andean foothills) where El Niño brings copious rain over this otherwise arid coastal area (e.g., Horel and Cornejo-Garrido, 1986). Rainfall variability over the eastern side of the equatorial Andes is more related with a dipole like correlation structure over the tropical Atlantic (Vuille et al., 2000). The tropical Andes also experience significant temperature anomalies during the ENSO phases with warming (cooling) up to $1^{\circ} \mathrm{C}$ during El Niño (La Niña) years. The precipitation deficit and atmospheric warming often results in a strongly negative mass balance in tropical Andes glaciers during El Niño events (Francou et al., 2004).

El Niño (La Niña) summers also bring less (more) precipitation to the Altiplano (Vuille et al., 2000; Garreaud and Aceituno, 2001) although the ENSO-rainfall relationship in this region is not too robust. During El Niño years the meridional thermal gradient between the tropics and subtropics becomes steeper, resulting in stronger westerly flow in the middle and upper troposphere over the central Andes. Consistently, there is less transport of moist air from the interior of the continent toward the Altiplano thus limiting the convection over the Plateau. In many cases, however, the zonal wind anomalies change sign over the Altiplano resulting in an alternation of wet/dry conditions between the northern and southern part of the Plateau (Vuille and Keiming, 2004). The ENSO-related temperature anomalies become weaker over the Altiplano, but still there is a tendency of warmer conditions during El Niño episodes.

Rainfall records from low-altitude stations in Central Chile $\left(27-35^{\circ} \mathrm{S}\right)$ clearly show above (below) normal rainfall totals during El Niño (La Niña) years (Montecinos and Aceituno, 2000). This warm/wet - cold/dry tendency is also evident in 

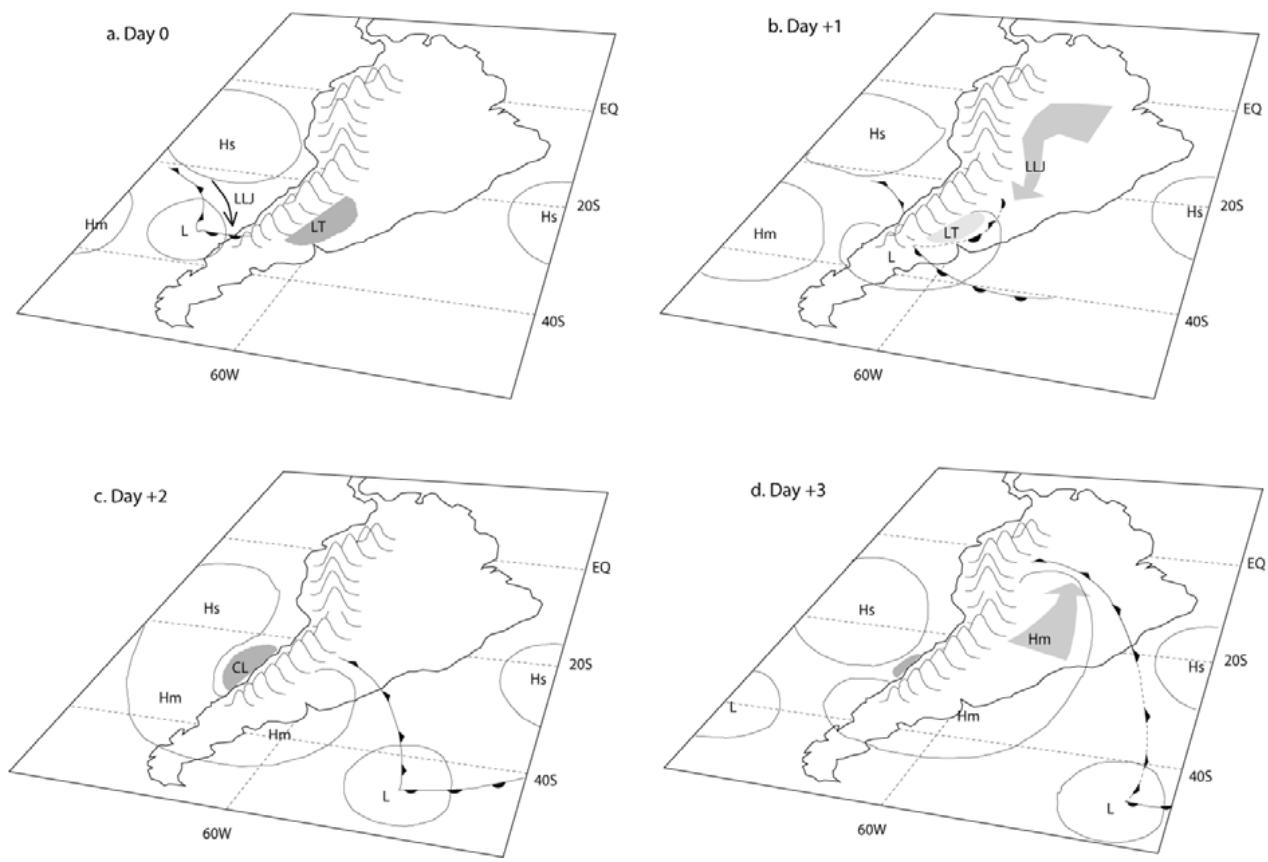

Fig. 6. Conceptual model of a mid-latitude wave moving across South America (for sake of clarity, only surface and low-level features are shown). Solid lines represent isobars at the surface. Recall the clockwise (counter-clockwise) circulation of the geostrophic winds around a low (high) pressure cell in the SH. The symbols are as follows: Hs=subtropical anticyclone; Hm=migratory (cold) anticyclone; L=migratory low pressure cell; LT=lee trough; $C L=$ coastal low. Also shown are surface cold fronts (solid lines with filled triangles), warm fronts (solid lines with filled semi circles), the approximate position of the low-level jet (LLJ, shaded arrow) and the path of the cold air surge (shaded arrow pointing northward). The whole sequence takes about 4 days. See text for details.

the snow pack over the subtropical Andes (Masiokas et al., 2006) and the stream flow in Andean rivers (Aceituno and Garreaud, 1995). The precipitation increase over the subtropical Andes is largely due to a higher frequency of midlatitude storms crossing this area (from the Pacific) during winter as a result of a blocking of the westerly flow and storm tracks over the southeast Pacific (Rutllant and Fuenzalida, 1991). The same blocking activity is responsible for a slight decrease of precipitation in southern Chile (around $40^{\circ} \mathrm{S}$ ) in austral spring during El Niño years (Montecinos and Aceituno, 2000).

Farther south, over the Austral Andes, there is no clear ENSO signal in precipitation or temperature. In contrast, the Southern Annual Mode (SAM, e.g., Thompson and Wallace 2000), an atmospheric mode of circulation characterized by pressure anomalies of one sign centered in the Antarctic and anomalies of opposite sign on a circumpolar band at about $40-50^{\circ} \mathrm{S}$, appears to modulate the air temperature over the southern tip of South America (Gillet et al., 2006; Garreaud et al., 2008). There is a well documented trend of SAM toward its positive polarity in the last three decades, featuring stronger westerlies and warmer air temperatures across much of Patagonia.

\section{Synoptic-scale systems}

Synoptic-scale disturbances are tropospheric-deep phenomena embedded in the midlatitude westerly flow, with a horizontal scale of thousands of kilometres and lifetimes of several days that produce most of the day-to-day weather changes in subtropical and extratropical latitudes. These disturbances feature a low and high pressure centre at the surface, and a trough-ridge couplet aloft, usually moving eastward at about $5-10 \mathrm{~m} / \mathrm{s}$ (e.g., Holton, 1992). The cyclonic circulation around the surface low is conducive to the formation of cold and warm fronts, elongated bands of intense thermal gradient, where localized ascent produces abundant cloudiness and precipitation. Although each baroclinic wave evolves in a unique form, they tend to move along rather narrow latitudinal bands known as storm tracks (e.g., Hoskins and Valdes 1990). In the Southern Hemisphere, the circumpolar storm track intersect the continent between $40^{\circ}-$ $50^{\circ} \mathrm{S}$ with only minor seasonal changes (e.g., Nakamura and Shimpo, 2004; Garreaud, 2007) although some systems approach South America at subtropical latitudes during winter. These systems are blocked by the Andes cordillera and experience substantial distortion in their structure (e.g., Berbery and Vera, 1996; Seluchi et al., 1998, 2006). 
To further describe the effect of the Andes on baroclinic waves, the evolution of a surface low-high couplet moving across South America is schematized in Fig. 6. The westerly component of the low-level flow ahead of the cold front is largely blocked by the Andes, producing a northerly jet along the coast of south-central Chile (Fig. 6a). This results in enhanced convergence of moist air and precipitation in southern Chile (around $35-40^{\circ} \mathrm{S}$ ) and inhibits the advance of the cold front into subtropical latitudes, contributing to the marked meridional precipitation gradient along the western slope of the Andes (Barret et al., 2009). Above $\sim 3000 \mathrm{~m}$ a.s.l. level, however, the westerly flow is no longer blocked by the Andes but rather forced to ascend, resulting in pre-frontal precipitation enhancement over the subtropical Andes as far north as $30^{\circ} \mathrm{S}$ (Barret et al., 2009; Viale and Norte, 2009). Indeed, the few high-altitude records suggest that orographic air uplift produces 2-3 times more annual precipitation up in the Andes relative to the coastal values at the same latitudes (Falvey and Garreaud, 2007; Favier et al., 2008).

At the same time (Fig. 6a), the strong westerly flow over the ridge produce lee-side subsidence in western Argentina leading to the formation of a thermal-orographic low just east of the Andes (Seluchi et al., 2003a). During summer, this lee-side effect deepens the climatological Chaco low, which in turn intensifies the transport of moist air from the north fuelling severe storms in the form of prefrontal squall lines (Garreaud and Wallace, 1998). Once the midlatitude surface low moves into Argentina, it merges with the thermal low east of the subtropical Andes (Fig. 6b). The deep low in the surface and the strong westerlies aloft act in concert to produce, under some conditions, severe damaging downslope wind storms along the eastern foothills of the Andes, locally known as Zonda events (Seluchi et al., 2003b). The Zonda is a close relative to other downslope wind systems, as the Foehn in central Europe (e.g., Klemp and Lilly, 1975) and the Chinook east of the Canadian Rockies (e.g., Zydek, 2000).

Returning to the synoptic sequence of Fig. 6, as the surface low moves eastward into the Atlantic, a migratory, coldcore anticyclone approaches the western coast of the continent and merges with the SE Pacific subtropical anticyclone (Fig. 6c). Off the coast of central Chile, the easterly, geostrophic winds in the lower troposphere force downslope flow over the Andean slope, so that cool marine air is replaced by warm, continental air. Consequently, the surface pressure drops along the subtropical west coast of the continent, leading to the formation of a coastal low and broad clearing of the stratocumulus clouds over the subtropical SE Pacific (Garreaud et al., 2002) with significant impacts on regional weather. To the east side of the subtropical Andes, the easterly flow in the northern flank of the migratory high is dammed by the mountains, breaking down the geostrophic balance and leading to southerly wind over a band of about $1000 \mathrm{~km}$ away from the Andean slopes (Fig. 6d). The cold, dry air surges equatorward between the Andes and the Brazil- ian plateau, displacing relatively warm, moist air. This later effect results in a hydrostatic surface pressure rise, explaining the expansion of the surface anticyclone into subtropical and tropical latitudes (e.g., Garreaud, 1999b). Thus, the occurrence of a warm coastal low to the west of the subtropical Andes and a cold core anticyclone to the east tends to be simultaneous, being both phenomena a consequence of the topographic disruption of a migratory midlatitude system (Seluchi et al., 2006).

South American cold surges are a year round feature of the synoptic climatology of the region (Garreaud, 2000; Vera and Vigliarolo, 1999; Seluchi and Marengo, 2000), with a near weekly periodicity, but with a large range in their intensity and meridional extent. Extreme wintertime episodes (one every few years) produce near freezing conditions and severe agricultural damage from central Argentina to southern Bolivia and Brazil (locally known as friagems or geadas; e.g. Marengo et al., 1997). In some extreme cases, the cold air can reach very low latitudes (and even cross the equator) affecting the eastern slopes of the Ecuadorian Andes (e.g., Emck, 2007). Summertime episodes produce less dramatic fluctuations in temperature and pressure but they are accompanied by synoptic-scale bands of heavy clouds at the leading edge of the cool air. The banded cloud pattern extends from the eastern slopes of the Andes southeastward and can reach as far as the northern coast of the continent (e.g., Garreaud and Wallace, 1998).

Acknowledgements. The author thanks two anonymous reviewers and Dave Rahn for constructive criticism of the original manuscript. This work was partially supported by CONICYT Chile Grant ACT-19.

Edited by: P. Fabian

Reviewed by: two anonymous referees

\section{References}

Aceituno, P.: Elementos del clima en el altiplano sudamericano, Revista Geofísica (IPGH), 44, 37-55, 1993.

Aceituno, P. and Garreaud, R.: Impacto de los fenómenos El Niño y La Niña en regimenes fluviométricos andinos. Revista de la Sociedad Chilena de Ingeniería Hidráulica, 10, 33-43, 1995

Adler, R., Huffman, G. J., Chang, A., Ferraro, R., Xie, P. P., Janowiak, J., Rudolf, B., Schneider, U., Curtis, S., Bolvin, D., Gruber, A., Susskind, J., Arkin, P., and Nelkin, E.: The Version-2 Global Precipitation Climatology Project (GPCP) Monthly Precipitation Analysis (1979-Present), J. Hydrometeorol., 4, 11471167, 2003.

Barrett, B. S., Garreaud, R., and Falvey, M.: Effect of the Andes cordillera on precipitation from a midlatitude cold front, Mon. Weather Rev., Mon. Weather Rev., doi:10.1175/2009MWR2881.1, in press, 2009.

Bendix, J., Rollenbeck, R., and Reudenbach, C: Diurnal patterns of rainfall in a tropical Andean valley of southern Ecuador as seen by a vertically pointing K-band Doppler radar, Int. J. Climatol., 26, 829-846, 2005. 
Berbery, E. H. and Vera, C. S.: Characteristics of the Southern Hemisphere winter storm track with filtered and unfiltered data, J. Atmos. Sci., 53, 468-481, 1996.

Diaz, H.F., and Markgraf, V.: El Niño. Cambridge University Press. Cambridge, UK, 1992.

Díaz, A. and Aceituno, P.: Atmospheric Circulation Anomalies during Episodes of Enhanced and Reduced Convective Cloudiness over Uruguay, J. Climate, 16, 3171-3185, 2003.

Ehlers, T. and Poulsen, C.: Influence of Andean uplift on climate and paleoaltimetry estimates, Earth Planet. Sci. Lett., 281(3-4), 238-248, 2009.

Falvey, M. and Garreaud, R.: Moisture variability over the South American Altiplano during the SALLJEX observing season, J. Geophys. Res., 110, D22105, doi:10.1029/2005JD006152, 2005.

Falvey, M. and Garreaud, R.: Wintertime precipitation episodes in central Chile: Associated meteorological conditions and orographic influences. J. Hydrometeorol., 8, 171-193, 2007.

Favier, V., Falvey, M., Rabatel, A., Praderio, E. and López, D.: Interpreting discrepancies between discharge and precipitation in high-altitude area of Chile's Norte Chico region $\left(2632^{\circ} \mathrm{S}\right)$, Water Resour. Res., 45(2), W02424, doi:10.1029/2008WR006802, 2008.

Francou, B., Vuille, M., Favier, V., and Cáceres, B.: New evidence for an ENSO impact on low latitude glaciers: Antizana 15, Andes of Ecuador, $0^{\circ} 28$ S, J. Geophys. Res., 109, D18106, doi:10.1029/2003JD004484, 2004.

Garreaud, R. and Wallace, J.: Summertime incursions of midlatitude air into subtropical and tropical South America, Mon. Weather Rev., 126, 2713-2733, 1998

Garreaud, R.: Multiscale analysis of the summertime precipitation over the central Andes, Mon. Weather Rev., 127, 901-921, 1999a.

Garreaud, R.: Cold air incursions over subtropical and tropical South America: A numerical case study, Mon. Weather Rev., 127, 2823-2853, 1999b.

Garreaud, R.: Cold air incursions over subtropical South America: Mean structure and dynamics, Mon. Weather Rev., 128, 25442559, 2000.

Garreaud, R. D. and Aceituno, P.: Interannual rainfall variability over the South American Altiplano, J. Climate, 14, 2779-2789, 2001.

Garreaud, R. and Rutllant, J.: Coastal lows along the subtropical west coast of South America: Numerical simulation of a typical case, Mon. Weather Rev., 131, 891-908, 2003.

Garreaud, R., Vuille, M., and Clements, A.: The climate of the Altiplano: Observed current conditions and past change mechanisms, Paleo3, 3054, 1-18, 2003.

Garreaud, R.: Precipitation and circulation covariability in the extratropics. Journal of Climate, 20, 4789-4797, 2007

Garreaud, R., Vuille, M., Compagnucci, R., and Marengo, J.: Present-day South American climate, Paleo3, doi:10.1016/j.paleo, in press, 2009.

Gillett N. P., Kell, N., and Jones, P.: Regional climate impacts of the Southern Annular Mode, Geophys. Res. Lett., 33, L23704, doi:10.1029/2006GL027721, 2006.

Holton, J.: An introduction to dynamic meteorology, Academic Press, 2002.

Hoskins, B. J. and Valdes, P. J.: On the Existence of Storm-Tracks, J. Atmos. Sci., 47, 1854-1864, 1990.
Horel J. and Cornejo-Garrido, A.: Convection along the Coast of Northern Peru during 1983: Spatial and Temporal Variation of Clouds and Rainfall, Mon. Weather Rev., 114, 2091-2105, 1986.

Houston, J. and Hartley, A.: The central Andean west-slope rainshadow and its potential contribution to the origin of hyperaridity in the Atacama Desert, Int. J. Climatol., 23(12), 14531464, doi:10.1002/joc.938, 2003.

Kalnay, E., Kanamitsua, M., Kistlera, R., Collinsa, W., Deavena, D., Gandina, L., Iredella, M., Sahaa, S., and White, G.: T he NCEP/NCAR 40-years reanalysis project, B. Am. Metorol. Soc., 77, 437-472, 1996.

Kalthoff, N., Bischoff-Gauß, I., Fiedler, F., et al.: Mesoscale wind regimes in Chile at 30 S, J. Appl. Meteorol., 41, 953-970, 2002.

Klemp, J. and Lilly, D.: Numerical simulation of hydrostatic mountain waves, J. Atmos. Sci., 35, 78-107, 1978

Legates, D. and Willmott, C.: Mean seasonal and spatial variability in gauge-corrected, global precipitation, Int. J. Climatol., 10, 111-127, 1990.

Lenters, J. and Cook, K.: Simulation and diagnosis of the regional summertime precipitation climatology of South America, J. Climate, 8, 2988-3005, 1995.

Lenters, J. D. and Cook, K. H.: On the origin of the Bolivian high and related circulation features of the South American climate, J. Atmos. Sci., 54, 656-677, 1997

López, M. and Howell, W.: Katabatic winds in the equatorial Andes, J. Atmos. Sci., 24, 29-35, 1967.

Marengo, J., Cornejo, A., Satyamurty, P., Nobre, C., and Sea, W.: Cold surges in tropical and extratropical South America: The strong event in June 1994, Mon. Weather Rev., 125, 2759-2786, 1997.

Marengo, J., Soares, C. Saulo, C., and Nicolini, M.: Climatology of the LLJ east of the Andes as derived from the NCEP reanalyses, J. Climate, 17, 2261-2280, 2004.

Masiokas, M., Villalba, R., Luckman, B., Le Quesne, C., and Aravena, J. C.: Snowpack Variations in the Central Andes of Argentina and Chile, 19512005: Large-Scale Atmospheric Influences and Implications for Water Resources in the Region, J. Climate, 19, 6334-6352, 2006.

Mitchell, T. P. and Wallace, J. M.: The annual cycle in the equatorial convection and sea surface temperature, J. Climate, 5, 11401156, 1992.

Montecinos, A., Díaz, A., and Aceituno, P.: Seasonal Diagnostic and Predictability of Rainfall in Subtropical South America Based on Tropical Pacific SST, J. Climate, 13, 746-758, 2000.

Nakamura, H. and Shimpo, A.: Seasonal Variations in the Southern Hemisphere Storm Tracks and Jet Streams as Revealed in a Reanalysis Dataset, J. Climate, 17, 1828-1844, 2004.

Poveda, G. and Messa, O.: Feedbacks between Hydrological Processes in Tropical South America and Large-Scale Ocean Atmospheric Phenomena, J. Climate, 10, 2690-2702, 1997.

Poveda, G., Mesa, O. J., Salazar, L. F., et al.: The diurnal cycle of precipitation in the tropical Andes of Colombia, Mon. Weather Rev., 133, 228-240, 2005.

Poveda, G., Rojas, W., Quiñones, M. L., et al.: Coupling between annual and ENSO timescales in the malaria-climate association in Colombia, Environ. Health Persp., 109, 489-494, 2001.

Rutllant, J. and Fuenzalida, H.: Synoptic Aspects of the Central Chile Rainfall Variability Associated with the Southern Oscillation, Int. J. Climatol., 11, 63-76, 1991. 
Rutllant, J. A., Fuenzalida, H., and Aceituno, P.: Climate dynamics along the arid northern coast of Chile: The 1997-1998 Dinámica del Clima de la Región de Antofagasta (DICLIMA) experiment, J. Geophys. Res., 108(D17), 4538, doi:10.1029/2002JD003357, 2003.

Saulo, A. C., Nicolini, M., and Chou, S. C.: Model characterization of the South American low-level flow during the 1997-98 springsummer season, Clim. Dynam., 16, 867-881, 2000.

Seluchi, M. E., Saulo, C., Nicolini, M., and Satyamurty, P.: The Northwestern Argentinean Low: A Study of Two Typical Events, Mon. Weather Rev., 131, 2361-2378, 2003.

Seluchi, M., Serafini, Y., and Le Treut, H.: The impact of the Andes on transient atmospheric systems: A comparison between observations and GCM results, Mon. Weather Rev., 126, 895-912, 1998.

Seluchi, M. and Marengo, J.: Tropical-midlatitude exchange of air masses during summer and winter in South America: Climatic aspects and examples of intense events, Int. J. Climatol., 20, 1020, 2000.

Seluchi, M., Saulo, A., Nicolini, M., and Satyamurty, P.: The Northwestern Argentinean Low: a study of two typical events, Mon. Weather Rev., 131, 2361-2378, 2003.

Seluchi, M., Garreaud, R., Norte, F., and Saulo, A.: Influence of the Subtropical Andes on Baroclinic Disturbances: A Cold Front Case Study. Mon. Weather Rev., 134(11), 3317-3335, 2006.

Smith, R. B. and Evans, J. P.: Orographic Precipitation and Water Vapor Fractionation over the Southern Andes, J. Hydrometeorol., 8, 3-19, 2007.

Thompson, D. W. J. and Wallace, J. M.: Annular Modes in the Extratropical Circulation. Part I: Month-to-Month Variability, J. Climate, 13, 1000-1016, 2000.

Trenberth, K. E.: Storm tracks in the Southern Hemisphere, J. Atmos. Sci., 48, 2159-2178, 1991.
Vera, C. and Vigliarolo, P.: A diagnostic study of cold-air outbreaks over South America, Mon. Weather Rev., 128, 3-24, 2000.

Vera, C., Higgins, W., Amador, J., Ambrizzi, T., Garreaud, R., Gochis, D., Gutzler, D., Lettenmaier, D., Marengo, J., Mechoso, C., Nogues-Paegle, J., Silva Diaz, P. L., and Zhang, C.: Towards a unified view of the American Monsoon System, J. Climate, 19, 4977-5000, 2006.

Viale, M. and Norte, F. A.: Strong Cross-Barrier Flow under Stable Conditions producing Intense Winter Orographic Precipitation: A Case Study over the Subtropical Central Andes, Weather Forecast., doi:10.1175/2009WAF2222168.1, in press, 2009.

Vuille, M.: Atmospheric circulation over the Bolivian Altiplano during dry and wet periods and extreme phases of the Southern Oscillation, Int. J. Climatol., 19, 1579-1600, 1999.

Vuille, M., Bradley, R., and Keimig, F.: Climate Variability in the Andes of Ecuador and Its Relation to Tropical Pacific and Atlantic Sea Surface Temperature Anomalies, J. Climate, 13, 25202535, 2000a.

Vuille, M., Bradley, R. S., and Keimig, F.: Interannual climate variability in the Central Andes and its relation to tropical Pacific and Atlantic forcing, J. Geophys. Res., 105, 12447-12460, 2000b

Vuille, M. and Keimig, F.: Interannual variability of summertime convective cloudiness and precipitation in the central Andes derived from ISCCP-B3 data, J. Climate, 17, 3334-3348, 2004.

Xie, P. and Arkin, P. A.: Global Precipitation: A 17-Year Monthly Analysis Based on Gauge Observations, Satellite Estimates, and Numerical Model Outputs, B. Am. Metorol. Soc., 78, 25392558, 1997.

Zidek, F.: Chinook wind. South Dakota Rev., 38, 1-15, 2000.

Zhou, J. and Lau, K. M.: Does a monsoon climate exist over South America?, J. Climate, 11, 1020-1040, 1998. 